\title{
Interleukin-33 in asthma: insights into pro-inflammatory roles of airway structural cells
}

\author{
D Préfontaine ${ }^{1 *}$, L Al-Awan ${ }^{1}$, AK Mogas ${ }^{1}$, S Audusseau', S Lajoie-Kadoch¹, R Olivenstein², J Chakir ${ }^{3}$, AJ Halayko ${ }^{4}$, \\ C Lemière $^{5}$, JG Martin'1 ${ }^{1}$ Q Hamid ${ }^{1 *}$ \\ From Canadian Society of Allergy and Clinical Immunology Annual Scientific Meeting 2009 \\ Halifax, Canada. 22-25 October 2009
}

\section{Background}

Interleukin-33 (IL-33) is a novel cytokine that triggers inflammatory immune responses, but evidence of its role in human asthma, a common allergic airway disease, is lacking. There is also a paucity of information regarding which cells express IL-33, and what conditions promote its expression. We sought to investigate whether IL-33 is expressed in the lung tissue from patients with asthma.

\section{Methods}

We obtained lung biopsy tissue specimens from asthmatic adults and from healthy control subjects, along with normal primary cells from human airways that were cultured in vitro. We studied expression of IL-33 in lung tissue specimens, and determined whether conditions seen in asthma promote IL-33 expression in vitro. We also assessed whether IL-33 expression is sensitive to glucocorticoid treatment.

\section{Results}

Higher expression of IL-33 is detected in lung tissue from asthmatic patients compared to control subjects. IL-33 expression correlates TNF- $\alpha$ e.g. a hallmark of inflammation. Airway epithelium, smooth muscle cells and endothelium are all sources of IL-33. When exposed to inflammatory conditions, in vitro cultured bronchial smooth muscle and epithelial cells increased their IL-33 expression, which surprisingly remained intracellular. Finally, glucocorticoid did not significantly reduce TNF$\alpha$-induced IL-33 expression.

\section{Conclusions}

Our study first describes IL-33 expression in asthma; it is increased in the lungs from asthmatics, and is

\footnotetext{
* Correspondence: qutayba.hamid@mcgill.ca

${ }^{1}$ Meakins-Christie Laboratories, Faculty of Medicine, McGill University, 3626 St-Urbain Street, Montreal, Qc, Canada H2X 2P2
}

enhanced under asthma-like in vitro conditions. IL-33 originates from structural cells of the airways and its expression does not respond to classic anti-inflammatory drug, thus reinforcing its relevance as a potential therapeutic target to treat asthma.

\section{Research funding sources}

Severe Asthma Program - Richard \& Edith Strauss Canada Foundation. J.T. Costello Memorial Research Fund. Fonds de Recherche en Santé du Québec.

\section{Author details \\ ${ }^{1}$ Meakins-Christie Laboratories, Faculty of Medicine, McGill University, 3626 St-Urbain Street, Montreal, QC, Canada H2X 2P2. ${ }^{2}$ Montreal Chest Hospital Research Institute, McGill University, Canada. ${ }^{3}$ Faculty of Medecine, Laval University, Quebec City, Canada. ${ }^{4}$ Faculty of Medecine, University of Manitoba, Canada. ${ }^{5}$ Sacré-Coeur Hospital, University of Montreal, Canada.}

Published: 12 May 2010

doi:10.1186/1710-1492-6-S1-P20

Cite this article as: Préfontaine et al:: Interleukin-33 in asthma: insights into pro-inflammatory roles of airway structural cells. Allergy, Asthma \& Clinical Immunology 2010 6(Suppl 1):P20.

Submit your next manuscript to BioMed Central and take full advantage of:

- Convenient online submission

- Thorough peer review

- No space constraints or color figure charges

- Immediate publication on acceptance

- Inclusion in PubMed, CAS, Scopus and Google Scholar

- Research which is freely available for redistribution

Submit your manuscript at www.biomedcentral.com/submit
C Biomed Central 